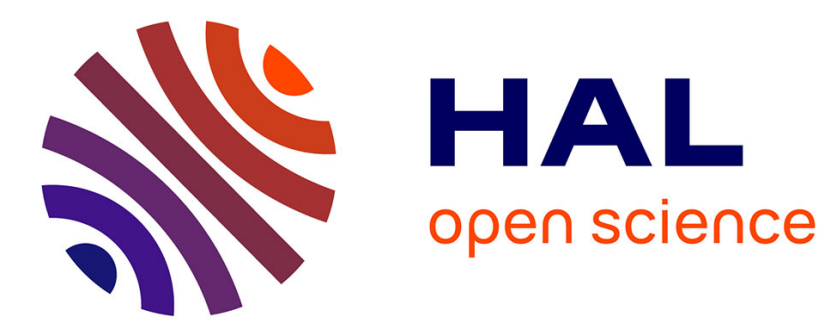

\title{
Impact of poplar water status on leaf-beetle (Chrysomela populi) survival and feeding
}

Sylvie La Spina, Jean-Claude Gregoire, Patrick Mertens, Charles De-Canniere

\section{To cite this version:}

Sylvie La Spina, Jean-Claude Gregoire, Patrick Mertens, Charles De-Canniere. Impact of poplar water status on leaf-beetle (Chrysomela populi) survival and feeding. Annals of Forest Science, 2010, 67 (2), 10.1051/forest/2009102 . hal-00883546

\section{HAL Id: hal-00883546 https://hal.science/hal-00883546}

Submitted on 1 Jan 2010

HAL is a multi-disciplinary open access archive for the deposit and dissemination of scientific research documents, whether they are published or not. The documents may come from teaching and research institutions in France or abroad, or from public or private research centers.
L'archive ouverte pluridisciplinaire HAL, est destinée au dépôt et à la diffusion de documents scientifiques de niveau recherche, publiés ou non, émanant des établissements d'enseignement et de recherche français ou étrangers, des laboratoires publics ou privés. 


\title{
Impact of poplar water status on leaf-beetle (Chrysomela populi) survival and feeding
}

\author{
Sylvie La SPINA ${ }^{1,2 *}$, Jean-Claude Gregoire ${ }^{1}$, Patrick MerTEns $^{3}$, Charles De-Canniere ${ }^{1}$ \\ ${ }^{1}$ Laboratoire de Lutte biologique et Ecologie spatiale, Université Libre de Bruxelles CP 160/12, Av. F. D. Roosevelt 50, 1050 Bruxelles, Belgium \\ ${ }^{2}$ Fonds National de la Recherche Scientifique (F.R.S.-FNRS), Belgium \\ ${ }^{3}$ DG03 - Département de l'Étude du Milieu Naturel et Agricole, Ministère de la Région Wallonne, Avenue Maréchal Juin 23, 5030 Gembloux, \\ Belgium
}

(Received 10 February 2009; accepted 4 April 2009)

Keywords:

water deficit /

tree-insect relationships /

herbivory /

drought stress /

Populus

\begin{abstract}
- The aim of this study is to assess the impact of drought on insect-tree relationships. Survival and feeding performances of leaf-beetles, Chrysomela populi put in cages with leaves of host-plants submitted to different levels of water stress were compared.

- Ninety 1-year-old poplar (Populus $\times$ euramericana) cuttings were grown in a greenhouse, and distributed into 3 groups submitted to different water treatments during six weeks. Adult C. populi were then encaged for four days with these cuttings, together with the five terminal leaves of a twig. Beetle survival and consumed leaf areas were then determined.

- Predawn leaf water potential values indicated that the drought treatments induced different levels of plant water stress. Plant height growth and total leaf numbers were reduced by plant stress. Beetle survival and leaf areas eaten were also reduced proportionally to plant water deficit.

- In conclusion, this experiment suggests that drought has a negative impact on $C$. populi survival and feeding.
\end{abstract}

Mots-clés :

déficit hydrique /

relations plantes-insectes /

herbivores /

sécheresse /

populus

\begin{abstract}
Résumé - Étude de l'influence d'un stress hydrique appliqué à des boutures de peuplier sur la survie et l'alimentation de chrysomèles phyllophages.

- L'objectif de ce travail est d'évaluer les effets d'une sécheresse sur les relations plantes-insectes. La survie et l'alimentation de chrysomèles phyllophages, Chrysomela populi, exposées à un hôte subissant divers niveaux de stress hydrique sont comparées.

- Quatre-vingt dix boutures de peuplier (Populus $\times$ euramericana) âgées d'un an ont été cultivées en serres, et réparties en trois groupes soumis à des traitements hydriques différents. Après un stress hydrique continu de six semaines, les boutures ont été exposées à des chrysomèles encagées avec les cinq dernières feuilles de rameaux, pour quatre jours. La survie et les surfaces foliaires consommées par les chrysomèles ont ensuite été déterminées.

- Les valeurs de potentiel hydrique foliaire de base indiquent que les traitements hydriques ont induit chez les plantes différents niveaux de stress hydriques. La croissance en hauteur des plantes ainsi que le nombre de feuilles ont été réduits par le stress hydrique. La survie des insectes et les surfaces foliaires consommées par ceux-ci ont également été réduites proportionnellement au déficit hydrique. - En conclusion, cette expérience suggère que la sécheresse a un impact négatif sur la survie et l'alimentation de C. populi.
\end{abstract}

\section{INTRODUCTION}

The increase of atmospheric greenhouse gas concentrations, essentially due to human activities, induces global climate change. Various observations point out an increase in the frequency, intensity and duration of extreme climatic events, such as droughts, floods, warm and cold waves (IPCC, 2001; Meehl and Tebaldi, 2004; Saxe et al., 2001).

\footnotetext{
*Corresponding author: slaspina@gmail.com
}

Drought is one of the most important factors limiting forest productivity (Loustau et al., 2005). When trees are subjected to water deficits, they acclimate through physiological and morphological changes, such as osmotic adjustment (Roberts et al., 1980; Zlatev, 2005), leaf area reduction (number of leaves and individual leaf area) (Van Volkenburgh, 1999), root elongation (Chen et al., 1997; Tschaplinski et al., 1998), stomatal conductance regulation (Chaves et al., 1991), etc. These changes enable trees to limit dehydration, and can interfere 
with plant-insect relationships via changes in leaf nutritional quality (nitrogen, water and metabolite content, leaf mechanical resistance), and host location (acoustic waves from cavitation, volatile metabolites, leaf colour) (see review by Mattson and Haack, 1987). The interaction can be either beneficial or disadvantageous for the insect, so that its overall response may be located on a gradient between two extremes: insects having better performances on stressed trees (Plant Stress Hypothesis, White, 1969) or choosing vigorous plants (Plant Vigour Hypothesis, Price, 1991), or a combination of both but in different life stages (Bjorkman, 1998).

The aim of this study was to assess the plant-mediated impact of soil water deficit on insect survival and feeding, and thus to observe changes in insect behaviour.

Poplar is used as a model tree, because of its rapid and pronounced responses to environmental conditions, notably drought and biotic factors, its easy vegetative reproduction and its worldwide studies (Bradshaw et al., 2000). Chrysomela populi (Coleoptera: Chrysomelidae), a well represented poplar pest in Europe, was chosen as an experimental insect. Its adults (males as well as females) and larvae feed on growing poplar leaves, frequently causing extensive damage in young plantations and short rotation stands (Augustin et al., 1993). Ideally, we should have worked with the entire life cycle of the insect. However, for practical reasons, this experiment had to be limited to a study of the adult stage feeding and survival.

In our experiments, we subjected trees to two water stress levels to test for non-linear responses by the insects, as recommended by Koricheva et al. (1998). As suggested by Huberty and Denno (2004), the phenology of stress, as well as the phenology of the plant, may be a key factor for insect success on stressed plants. Here, we chose to inflict a continuous water stress to the plants.

Soil water status was monitored using volumetric soil water content. This indicator allowed us to know the time of irrigation and the amount of water to give to each plant. Soil water content was maintained constant and different between water treatments. Plant water status was determined using predawn leaf water potential. This method is largely used (Cochard et al., 2001; Kramer, 1988; Turner, 1988). Drought has an important impact on poplar growth (Tschaplinski et al., 1998). Growth measurement can thus bring additional information on the stress undergone by the plants (Dobbertin, 2005). Plant growth was followed using two indicators: height growth and total leaf number. Survival and leaf areas eaten were chosen to reflect insect behaviour on plants.

\section{MATERIALS AND METHODS}

\subsection{Plant material}

We used Populus $\times$ euramericana (clone "RW401") as experimental trees. This clone is not known to be particularly tolerant or sensitive to insects. It was chosen for this rather neutral relationship to phytophages, and also because Populus $\times$ euramericana hybrids are quite common in Belgium. Ninety experimental cuttings were planted in $10 \mathrm{~L}$ plastic pots, in a mixture of sand-loam-peat, in March
2005. They were grown outdoors until 5 April 2006, when they were moved for the experiment into a greenhouse on campus at the Université Libre de Bruxelles. Budburst was induced by a temperature of $20{ }^{\circ} \mathrm{C} / 25^{\circ} \mathrm{C}(\mathrm{n} / \mathrm{d})$. Temperature during the experiment ranged from 15 to $45{ }^{\circ} \mathrm{C}$ and relative humidity ranged from $33 \%$ to $95 \%$. Cuttings were exposed to natural daylight. They were fertilized with N-P-K: 6-3-3 on 21 April 2006 (4.2 g/pot) and on 27 May 2006 (2.1 g/pot). A complement of chelated iron (EDTA, Chelosan, $50 \mathrm{~g} / 10 \mathrm{~L}$ water) was added during this last intervention. Biological control was applied in the greenhouse against thrips (predator: Amblyseius cucumeris) and acarina (predators: Feltiella acarisuga, Amblyseius californicus, Phytoseiulus persimilis) (Biobest Biological Systems). Pest infestations were kept under critical level, but it is possible that pest attacks could have activated plant defense systems, with an impact on herbivore feeding and survival. We have observed that plants from all treatments were similarly infested by mites. Mite density was the same on $\mathrm{M}, \mathrm{S}$ or T cuttings. So, if plant defences were activated by this pest attack, they would have been equally activated in the different water treatments, and this could not explain the treatment effects observed on C. populi.

\subsection{Insects}

Two hundred young adults of Chrysomela populi were collected on poplars in Orléans (France) and brought back to the lab. They were fed with Populus nigra leaves during two days until the beginning of exposure to the experimental plants.

\subsection{Experimental design}

The ninety cuttings were distributed into 3 spatially randomized water treatments. The pots containing the " $T$ " cuttings (control) were disposed each on a $3.5 \mathrm{~cm}$ high dish kept full of water. Irrigation of the "M" (mild water stress) and "S" (severe water stress) cuttings was withheld from 9 May 2006, until expected soil water contents (13\% and $10 \%$ of volume respectively) were reached, on 14 May 2006 (=day0). They were then watered manually to keep soil water content constant. The choice of used water regimes is based on a predeterminated predawn leaf water potential - soil water content curve. Following this curve (not shown here but see Fig. 2), the threshold for stress initiation is about $13 \%$ soil water content. Predawn leaf water potential becomes critical when soil water content drops under $10 \%$. The soil water content range inducing plant stress is thus very sharp. We chose levels of soil water content, $13 \%$ for $\mathrm{M}$ treatment (moderate water stress) and $10 \%$ for $\mathrm{S}$ treatment (acute water stress).

\subsection{Water status}

Soil water content was measured every day or every second day with a conductivity meter (Thetaprobe ML2, DELTA-T DEVICES LTD, Cambridge, England). Measures were taken at three positions in each pot, using the average in the analyses. Plant water status was determined by measuring predawn leaf water potential twice a week, using a pressure chamber (Kramer, 1988; PMS Instrument Co., Corvallis, Oregon, USA). Leaves of rank 7 and 8 (7th and 8th leaves from the end of the tip) were chosen to avoid variability linked to leaf position. Measures were taken on 5 plants per treatment. 


\subsection{Plant vigour}

Height was measured every ten days, from 9 May to 28 June 2006, for all cuttings. Simultaneously, leaf numbers were determined on the same 18 randomly chosen cuttings per treatment. At the end of the experiment, all experimental plants were watered to soil saturation and monitored to verify that they would survive the stress treatments.

\subsection{Insect survival and feeding}

The exposure of cutting to insects began after $42 \mathrm{~d}$ of water stress, on 24 June 2006 (day 41) (period 1). Each Chrysomela populi adult was put in a cage with the 5 last leaves of a (non-detached) twig. Two twigs per cutting were used. The sex of the beetles was not checked. The cages were made each from two polystyrene Petri dish lids or bottoms kept pressed together over the leaves by rubber bands, and with the edges coated with polythene foam to ensure maximum tightness. Insect survival and leaf area eaten were determined four days later, and the experiment was repeated once on 30 June 2006 (day 47) (period 2). Leaf areas eaten were measured using an image processing program (MATLAB, The MathWorks, Inc., vers. 7.1) with scanned leaf pictures. Ideally, we should have measured the dry weight of the eaten portions of the leaves. The problem was to measure the initial weight of non-detached leaves. Since this was not possible we chose consumed area as a substitute, with the hypothesis that, on the average, the leaves which were measured had the same density.

\subsection{Statistical analysis}

Statistical analyses were performed using STATISTICA (StatSoft, inc., vers. 7.1). The statistical analysis of time series of measurements was carried out using a linear model where the treatment and time were considered as a factor and a continuous covariate, respectively. The linear model estimated the significance of the treatment, of time, and of the interaction treatment by time. This allowed controlling for the temporal dependency between observations. In the analysis of the soil water content data, we were primarily interested by the effect of the treatment, while in the analysis of the height growth data and total leaf number data, we were primarily interested by the interaction term, i.e. testing if the slope of the regression lines illustrated in Figure $3 \mathrm{~A}$ and $3 \mathrm{~B}$ differed. Survival data were analysed using Chisquare test, which is fairly conservative, as a mean to quantify if the proportion of dead individuals is homogeneously distributed in all three treatments. Leaf areas eaten data were analysed using a oneway ANOVA, to test for treatment and leaf rank effects.

\section{RESULTS}

\subsection{Water status}

The mean soil water contents (SWC, in volume) ( \pm standard deviation) of different series are: $50.2 \%( \pm 6.6 \%)$ for series $\mathrm{T}, 13.3 \%(+4.1 \%,-3.6 \%)$ for series $\mathrm{M}$, and $10.7 \%(+3.5 \%$, $-3.1 \%$ ) for series $\mathrm{S}$ (Fig. 1). A repeated measures ANOVA was performed on SWC data, and shows a statistical difference between all series (treatment term from the treatment by time full factorial model, $F_{(43,3960)}=45.266, p=0.0005$, post-hoc test:
Table I. $t$-tests on predawn leaf water potential values.

\begin{tabular}{lcccc}
\hline Day & Mean $\mathrm{S}^{*}(\mathrm{~N})$ & Mean $\mathrm{M}^{*}(\mathrm{~N})$ & $t$ & $p$ \\
\hline 2 & $0.49(10)$ & $0.36(10)$ & 8.55 & $<\mathbf{0 . 0 0 1}$ \\
5 & $1.01(10)$ & $0.55(10)$ & 3.80 & $\mathbf{0 . 0 0 1}$ \\
9 & $1.34(10)$ & $0.39(10)$ & 8.46 & $<\mathbf{0 . 0 0 1}$ \\
12 & $0.74(10)$ & $0.42(10)$ & 2.68 & $\mathbf{0 . 0 1 5}$ \\
\hline 16 & $1.55(10)$ & $1.14(10)$ & 2.64 & $\mathbf{0 . 0 1 6}$ \\
19 & $0.30(10)$ & $0.27(10)$ & 0.46 & 0.652 \\
23 & $0.87(10)$ & $0.57(10)$ & 3.47 & $\mathbf{0 . 0 0 3}$ \\
26 & $1.20(10)$ & $0.43(8)$ & 10.53 & $<\mathbf{0 . 0 0 1}$ \\
30 & $1.80(10)$ & $1.17(10)$ & 5.00 & $<\mathbf{0 . 0 0 1}$ \\
\hline 33 & $0.64(10)$ & $0.37(10)$ & 5.02 & $<\mathbf{0 . 0 0 1}$ \\
37 & $0.68(10)$ & $0.86(10)$ & -1.8 & 0.08 \\
44 & $0.60(10)$ & $0.44(10)$ & 5.5 & $<\mathbf{0 . 0 0 1}$ \\
47 & $1.91(8)$ & $0.73(8)$ & 5.7 & $<\mathbf{0 . 0 0 1}$ \\
\hline 51 & $0.50(10)$ & $0.39(10)$ & 1.7 & 0.105 \\
\hline
\end{tabular}

Mean S/M: mean value of predawn leaf water potential, N S/M: number of replicates, $t$ : Student's $t$ statistic, $p$ : associated $p$-value.

$P<0.001)$. Predawn leaf water potential (PLWP) increases exponentially, in absolute value, as soil water content drops below $13 \%$ (Fig. 2). This value makes a threshold for water stress initiation. Soil water content and predawn leaf water potential of control cuttings remain above $45 \%$ and $-0.5 \mathrm{MPa}$ respectively. Minimum soil water content and predawn leaf water potential for $\mathrm{S}$ cuttings are $7.6 \%$ and $-2 \mathrm{MPa}$. Predawn leaf water potentials of cuttings $\mathrm{M}$ and $\mathrm{S}$ are statistically different for 11 of the $14 \mathrm{~d}$ of measure (Tab. I).

\subsection{Plant vigour}

To quantify height growth, initial height was chosen as a reference point. Height increment of the cuttings is continuous during all the experiment, but faster for series $\mathrm{T}$ and slowest for series S. Series M is intermediate. After $44 \mathrm{~d}$ of stress treatments, cuttings height increased to $+52.6 \mathrm{~cm}( \pm 6.6 \mathrm{~cm})$ for series $\mathrm{T}$, to $+19.3 \mathrm{~cm}( \pm 5.5 \mathrm{~cm})$ for series $\mathrm{M}$, and to $+11 \mathrm{~cm}$ $( \pm 5.1 \mathrm{~cm})$ for series $\mathrm{S}$. A factorial ANOVA performed on logtransformed data shows a statistical difference between series through time (interaction term from the treatment by time full factorial model: $\left.F_{(8,331)}=29.615 ; p<0.00005\right)$. At the beginning of the stress experiment (day 0), there is no statistical difference between series. S-N-K post-hoc shows a statistical difference $(p<0.00005)$ between control (T) and stressed cuttings (M and $\mathrm{S}$ ) appearing on day10, and, on days 21, 31 and 44 , all series are statistically different $(p<0.00005)$.

Plant leaf number is also reduced proportionally to water deficit. To quantify this, we used the initial number of leaves as a reference point. Under well-watered conditions, the total leaf number reaches initials $+29( \pm 16)$ leaves. In response to water stress, plant leaf number is reduced to initials $-6( \pm 10)$ for series M, and to only initials $-27( \pm 14)$ for series $S$. The older leaves of cuttings $\mathrm{M}$ and $\mathrm{S}$ senesced and abscised, while 


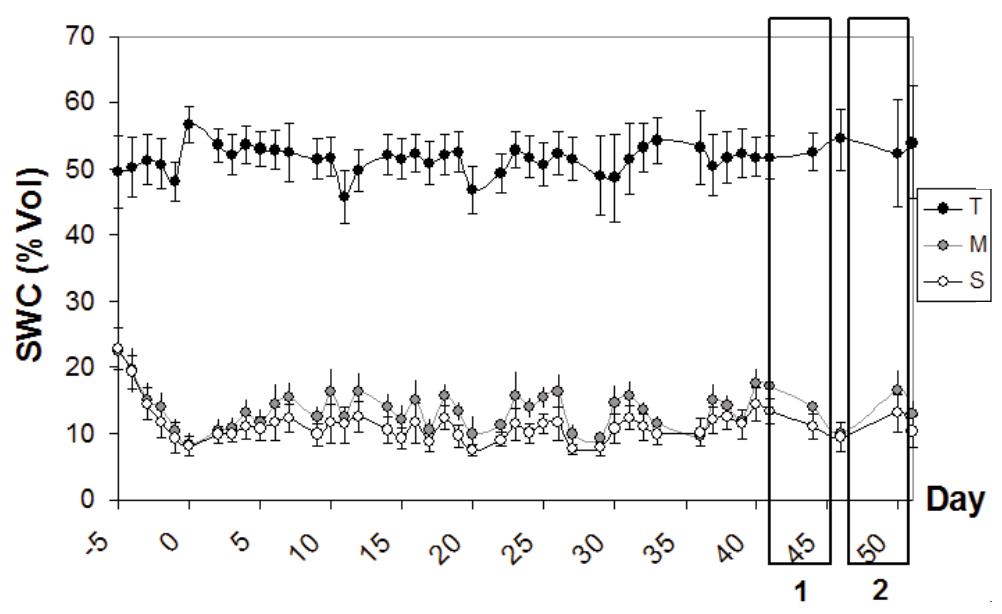

Figure 1. Temporal changes in soil water content (SWC) of control cuttings (T), moderately water-stressed cuttings (M), and severely waterstressed cuttings (S). The two numbered rectangular boxes represent the periods of exposure to Chrysomela populi.

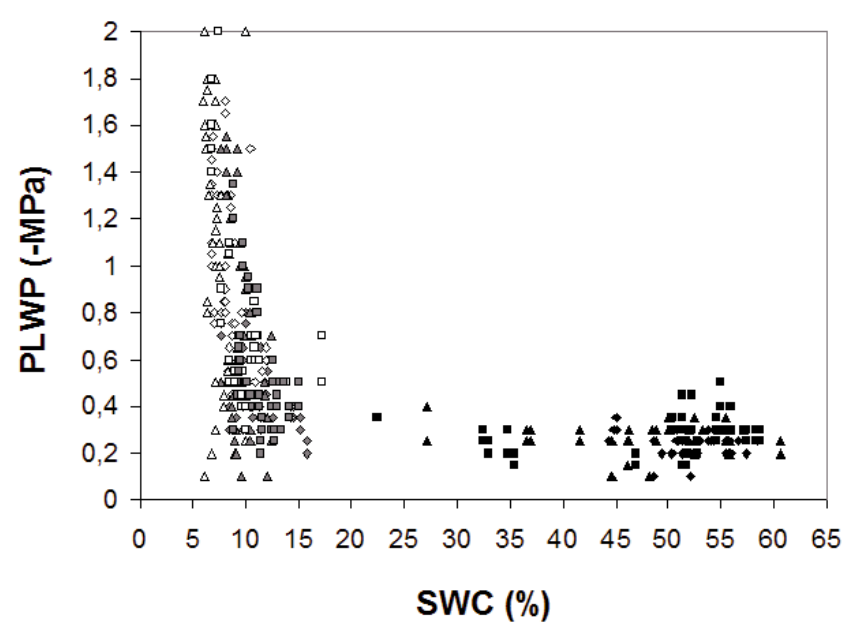

Figure 2. Relationship between predawn leaf water potential (PLWP) and soil water content (SWC). T (black): control cuttings, M (grey): moderate water-stress, S (white): severe water-stress. Diamonds: from $12 / 05$ to $26 / 05$, triangles: from $30 / 05$ to $13 / 06$, squares: from $16 / 06$ to $04 / 07$.

new leaf production was slower. No expanding leaf desiccated. A statistical difference between series through time was also confirmed by a factorial ANOVA (interaction term from the treatment by time full factorial model: $F_{(8,253)}=29.996 ; p<$ $0.00005)$. A same trend as height increment was observed in SN-K post-hoc results: no statistical differences between series for day 0 , a statistical difference on day 10 between $\mathrm{T}$ and $\mathrm{M}$ $\mathrm{S}(p<0.0001)$, and then a statistical difference between all series for days 21,31 and $44(p<0.00005)$.

All study plants survived the drought stress treatment. After being watered, they resumed growth and produced new leaves.

\subsection{Insect survival and feeding}

Survival declines with increasing plant water stress, and drops to $52 \%$ in the driest treatment, compared to $98 \%$ in con- trol (Fig. 3A). Survival in treatment $\mathrm{M}$ is intermediate (77\%). The same trend is observed for the second period of the experiment (Fig. 3B), but overall survival is much lower, probably because of exceptionally warm temperatures in the greenhouse (maximal daily temperature rose above $35^{\circ} \mathrm{C}$ during the $4 \mathrm{~d}$ of exposure). Survival differs statistically between series in both periods of exposure (Period 1: overall $\mathrm{Chi}^{2}=28.8$; $\mathrm{d} f=2 ; N=157 ; p<0.001$ ) (Comparison between $\mathrm{M}$ and $\mathrm{S}$ : $\mathrm{Chi}^{2}=7.3, \mathrm{~d} f=1, p=0.007<0.016$; Bonferroni correction for three simultaneous tests), (Period 2: overall $\mathrm{Chi}^{2}=17.7$; $\mathrm{d} f=2 ; N=128 ; p<0.001$ ) (Comparison between $\mathrm{M}$ and $\mathrm{S}$ : $\mathrm{Chi}^{2}=1.875, \mathrm{~d} f=1, p=0.17>0.016$; Bonferroni correction for three simultaneous tests).

Leaf areas eaten are reduced with water stress (Fig. 4). A one-way ANOVA shows a difference between stressed and non-stressed cuttings, but SNK post-hoc tests do not discriminate $\mathrm{M}$ and $\mathrm{S}$ treatments (Period 1: $F_{(2,82)}=7.42$; $p=0.001$; SNK: $\alpha=0.002$; Period 2: $F_{(2,90)}=7.73$; $p=0.0008$; SNK: $\alpha=0.002$ ). To take into account the interdependency between the two periods of exposure to the insects, as the same cuttings were used, we divided the degrees of freedom of parametric tests by half. The tests remain significant (Period 1: $F_{(2,41)}=7.42 ; p=0.002$; Period 2: $\left.F_{(2,45)}=7.73 ; p=0.001\right)$.

Individual leaf areas eaten over $15 \mathrm{~cm}^{2}$ are only found for beetles feeding on T cuttings ( $24 \%$ cases for period 1 and $33 \%$ cases for period 2). Young leaves (rank $\leq 3$ ) are preferentially attacked by the beetles (one-way ANOVA, $F_{(4,509)}=9.71 ; p<$ 0.001) (Fig. 5).

\section{DISCUSSION}

The soil water contents maintained during the experiment permitted to keep 3 series of 30 poplar cuttings with different levels of water stress, as indicated by predawn leaf water potential values. A $40 \mathrm{~d}$ continuous water stress was maintained before the beginning of the herbivore experiment. The reduced plant vigour caused by water deficit is shown by the decrease 

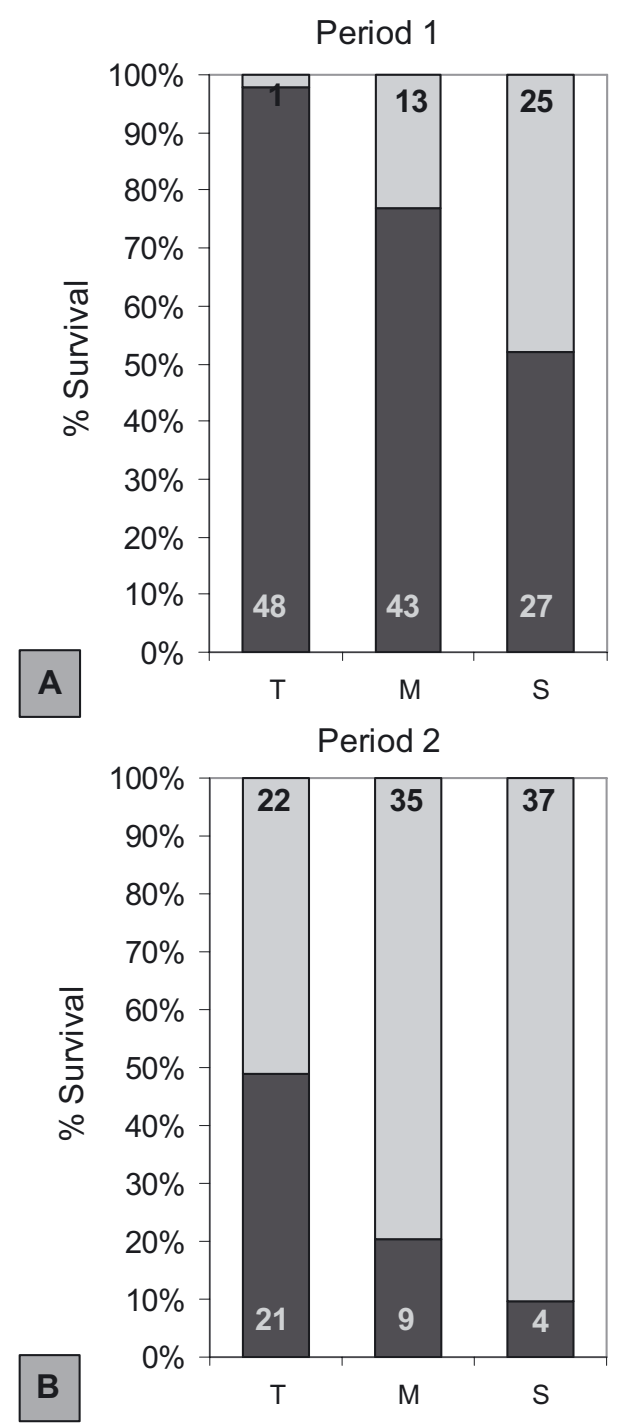

Figure 3. Leaf-beetle survival during the first (Fig. 4A) and second (Fig. 4B) periods of exposure to poplar. T: control cuttings, M: moderate water-stress, $S$ : severe water-stress. Numbers in the boxes represent the numbers of leaf-beetles for each case. Black: survival, grey: mortality.

in height growth and total leaf numbers. On the stressed plants, the survival of $C$. populi adults and leaf areas eaten were reduced. According to these results, leaf-beetle survival and feeding seem to be reduced with host-plant water stress.

Insect survival was surprisingly low in the second five-day feeding assay relative to the first. Air temperature during the second feeding assay was extremely warm, and could have affected beetle survival. But, as in period 1, an effect of water treatments on beetle survival was highlighted.

Water stress can induce biochemical changes in leaves, such as a decrease in water content (Braatne et al., 1992; Marron et al., 2002), an increase in nitrogen content (White, 1969; 1984) and changes in condensed tannins and phenylglucoside concentrations. According to the Plant Growth-Differentiation

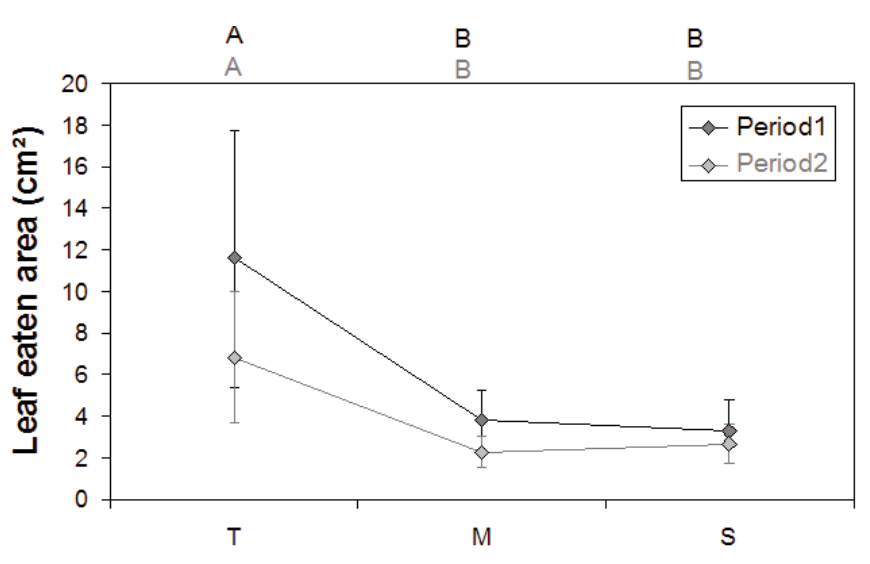

Figure 4. Leaf areas consumed by leaf-beetle in the different series, for the two periods of exposure. T: control cuttings, M: moderate water-stress, $\mathrm{S}$ : severe water-stress. Mean \pm 0.95 Conf. Interval. Groups with different letters A, B, C are statistically different.

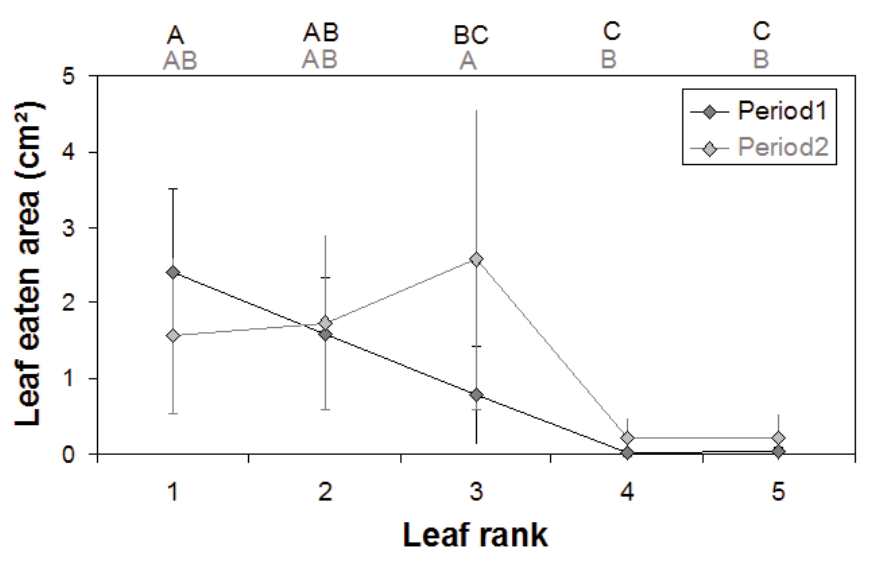

Figure 5. Leaf area eaten by leaf rank for both periods of exposure. Leaves of rank 1 are the youngest. T: control cuttings, M: moderate water-stress, $\mathrm{S}$ : severe water-stress. Mean \pm 0.95 Conf. Interval. Groups with different letters A, B, C are statistically different.

Balance Hypothesis (Cronin and Hay, 1996; Herms and Mattson, 1992; Stamp, 2004), water and nutrient stresses cause plant growth inhibition more than they slow photosynthesis. This induces an accumulation of soluble carbohydrates, which are allocated to the differentiation pathway. Thus, a mild water stress would reinforce tree defences against herbivores and pathogens. But in the case of a severe water stress, both growth and photosynthesis are inhibited, and the production of carbohydrates is stopped. Plant defense against herbivores should thus be lower. A parabolic response of herbivores and pathogens performances to tree water status is then expected. In our experiment, we subjected trees to three stress levels (no stress, mild stress, severe stress) to test for non-linear responses by the insects (Koricheva et al., 1998). No parabolic response was found for insect survival, which was reduced proportionally to stress intensity. Regarding leaf areas eaten, no difference between mild and severe treatments can be highlighted in this experiment. 
Water stress seemed to induce changes in leaf quality and made it unsuitable for the insects. Drought stress can induce differences in leaf growth: leaves of stressed cuttings can have stopped their growth. As Chrysomela populi adults prefer growing leaves, this could also explain our results. Some physical properties of leaves can be altered by water stress. Leaf toughness can increase with cell walls thickening, and may be an obstacle for insect feeding (Kagata and Ohgushi, 2006; Matsuki and MacLean, 1994).

It would be of great interest to study the influence of water stress on leaf biochemistry and physical properties, in particular on phenylglucoside concentrations. This new approach may help to know which leaf characteristics are crucial for insect feeding. Plant selection using this knowledge could lead to a decrease in poplar susceptibility to chrysomelids, and to a better biomass production.

Acknowledgements: We thank Marius Gilbert for statistical advices, and Jean-Marc Molenberg and Luc Dekelver for technical assistance. The "DG03 Département de l'Étude du Milieu Naturel et Agricole" provided all plant material. We thank Sylvie Augustin and Jonathan Voise for insect collection in Orleans (France). This work complies with the current laws of Belgium.

\section{REFERENCES}

Augustin S., Courtin C., and Delplanque A., 1993. Preferences of Chrysomela (= Melasoma) populi $\mathrm{L}$. and Chrysomela tremulae F. (Coleoptera: Chrysomelidae) for Leuce section poplar clones. J. Appl. Entomol. 115: 370-378.

Bjorkman C., 1998. Opposite, linear and nonlinear effects of plant stress on a galling aphid. Scand. J. For. Res. 13: 177-183.

Braatne J.H., Hinckley T.M., and Stettler R.F., 1992. Influence of soil water on the physiological and morphological components of plant water balance in Populus trichocarpa, Populus deltoïdes and their F1 hybrids. Tree Physiol. 11: 325-339.

Bradshaw H.D., Ceulemans R., Davis J., and Stettler R., 2000. Emerging model systems on plant biology: poplar (Populus) as a model forest tree. J. Growth Regul. 19: 306-313.

Chaves M.M., Pereira J.S., Maroco J., Rodrigues M.L., Ricardo C.P.P., Osorio M.L., Carvalho I., Faria T., and Pinheiro C., 1991. How plants cope with water stress in the field. Photosynthesis and growth. Ann. Bot. 89: 907-916.

Chen S., Wang S., Altman A., and Hüttermann A., 1997. Genotypic variation in drought tolerance of poplar in relation to abscisic acid. Tree Physiol. 17: 797-803.

Cochard H., Forestier S., and Ameglio T., 2001. A new validation of the Scholander pressure chamber technique based on stem diameter variations. J. Exp. Bot. 52(359): 1361-1365.

Cronin G. and Hay M.E., 1996. Within-plant variation in seaweed palatability and chemical defenses: optimal defense theory versus the growth-differentiation balance hypothesis. Oecologia 105: 361-368.

Dobbertin M., 2005. Tree growth as indicator of tree vitality and of tree reaction to environmental stress: a review. Eur. J. For. Res. 124: 319-333.
Herms D.A. and Mattson W.J., 1992. The dilemma of plants: to grow or defend. Q. Rev. Biol. 67: 283-335.

Huberty A.F. and Denno R.F., 2004. Plant water stress and its consequences for herbivorous insects: a new synthesis. Ecology 85: 13831398.

IPCC, 2001. Climate change 2001. The scientific basis. Genève, IPCC, $944 \mathrm{p}$.

Kagata H. and Ohgushi T., 2006. Nitrogen homeostasis in a willow leaf beetle, Plagiodera versicolora, is independent of host plant quality. Entomol. Exp. Appl. 118: 105-110.

Koricheva J., Larsson S., and Haukioja E., 1998. Insect performance on experimentally stressed woody plants: a meta-analysis. Annu. Rev. Entomol. 43: 195-216.

Kramer P.J., 1988. Measurement of plant water status: historical perspectives and current concerns. Irrig. Sci. 9: 275-287.

Loustau D., Bosc A., Colin A., Ogée J., Davi H., François C., Dulrene E., Déqué M., Cloppet E., Arronays D., Le Bas C., Saby N., Pignard G., Hamza N., Granier A., Bréda N., Ciais P., Viovy N., and Delage F., 2005. Modeling climate change effects on the potential production of French plains forests at the sub-regional level. Tree Physiol. 25: 813-823.

Marron N., Delay D., Petit J.M., Dreyer E., Kahlem G., Delmotte F.M., and Brignolas F., 2002. Physiological traits of two Populus $\times$ euramericana clones, Luisa Avanzo and Dorskamp, during a water stress and re-watering cycle. Tree Physiol. 22: 849-858.

Matsuki M. and MacLean S.F., 1994. Effects of different leaf traits on growth rates of insect herbivores on willows. Oecologia 100: 141152.

Mattson W.J. and Haack R.A., 1987. The role of drought in outbreaks of plant-eating insects. BioScience 37: 110-118.

Meehl G.A. and Tebaldi C., 2004. More intense, more frequent, and longer lasting heat waves in the 21st Century. Science 305: 994-997.

Price P.W. 1991. The plant vigor hypothesis and herbivore attack. Oikos 62: 244-251.

Roberts S.W., Strain B.R., and Knoerr K.R., 1980. Seasonal patterns of leaf water relations in four co-occuring forest tree species: parameters from pressure-volume curves. Oecologia 46: 330-337.

Saxe H., Cannell M.G.R., Johnsen B., Ryan M.G., and Vourlitis G., 2001. Tree and forest functioning in response to global warming. New Phytol. 149: 369-399.

Stamp N. 2004. Can the growth-differentiation balance hypothesis be tested rigorously? Oikos 107: 439-448.

Tschaplinski T.J., Tuskan G.A., Gebre G.M., and Todd D.E., 1998. Drought resistance of two hybrid Populus clones grown in a largescale plantation. Tree Physiol. 18: 653-658.

Turner N.C., 1988. Measurement of plant water status by the pressure chamber technique. Irrig. Sci. 9: 289-308.

Van Volkenburgh E., 1999. Leaf expansion - an integrating behaviour. Plant Cell Environ. 22: 1463-1473.

White T.C.R., 1969. An index to measure weather-induced stress of trees associated with outbreaks of psyllids in Australia. Ecology 50: 905909.

White T.C.R., 1984. The abundance of invertebrate herbivores in relation to the availability of nitrogen in stressed food plants. Oecologia 63: 90-105.

Zlatev Z.S., 2005. Effects of water stress on leaf water relations of young bean plants. Central Eur. J. Agric. 6: 5-14. 